\title{
ОРГАНИЗАЦИОННО-ЭКОНОМИЧЕСКИЙ МЕХАНИЗМ \\ ИСПОЛЬЗОВАНИЯ ПОДЗЕМНЫХ ВОД В РЕСПУБЛИКЕ БЕЛАРУСЬ
}

\section{Е.В. СКВОРЦОВА}

К.Э.H.

Аннотация:

Статья посвящена анализу сложившегося в Республике Беларусь организационно-экономического механизма использования подземных вод. Оценка механизма произведена по ключевым направлениям применения пресной и минеральной воды: разведка, добыча и потребление. Выявлены основные проблемы эксплуатации подземных вод в разрезе исследуемых направлений, предложены концептуальные положения совершенствовании организационноэкономического механизма использования подземных вод Республики Беларусь.

\section{ВВЕДЕНИЕ}

В Республике Беларусь исследования водных ресурсов ведутся с начала 20 века. В разные годы их изучением занимались Богомолов Г.В., Волчек А.А., Калинин М.Ю., Киселев П.А., Козлов М.Ф.,Кудельский А.В., Куксин И.Е. Курило К.А., Махнач А.С., Маковеев А.А., Маркова А.П., Мурашко М.Г., Станкевич Р.А., Стефаненко А.Я., Цапенко М.М. и многие другие. Однако их исследования посвящены, в основном, теоретическим и практическим вопросам гидрогеологии.

Некоторые экономические аспекты использования водных ресурсов в республике рассматривали Головач С.В., Кашицкий Э.С., Кирвель И.И., Киреенко Е.Г., Шершнев О.В., Ясовеев М.Г. и другие. Эти авторы уделяли внимание, в основном, вопросам использования воды в сельском хозяйстве и промышленности, оценке ее как части природно-ресурсного потенциала, разработке тарифов и налогов за пользование водой в республике.

Анализ литературных источников, связанных с исследованием подземных водных ресурсов в Республике Беларусь, показал, что в основном учеными рассматриваются гидрогеологические аспекты: объемы запасов, происхождение, химический состав, условия залегания подземных вод. Подземные воды в экономике любой страны используются для удовлетворения различных нужд - хозяйственно-бытовых, питьевых, лечебных, курортных, оздоровительных, а также сельскохозяйственных, промышленных и иных потребностей. Повышение эффективности использования такого важного ресурса требует применения комплексного подхода.

В связи с вышесказанным оценка организационно-экономического механизма использования подземных вод в Республике Беларусь по основным це- 
лям - разведка, добыча и потребление - является актуальным и перспективным направлением научных исследований.

\section{РЕЗУЛЬТАТЫ И ИХ ОБСУЖДЕНИЕ}

Теоретические подходы к исследованию «механизмов» в экономике

Понятие «механизм» в экономическом контексте используется отечественными учеными еще с начала 20 века. Впервые понятие «хозяйственный механизм» применительно к системе способов ведения хозяйства в современных условиях было использовано в постановлении Совета Министров СССР от 12 июля 1979 г. «Об улучшении планирования и усилении воздействия хозяйственного механизма на повышение эффективности производства и качество работы» [1]. В советские годы понятие «хозяйственный механизм» трансформировалось в связи с разработкой и внедрением комплекса мер по его совершенствованию. Однако кардинальным образом подходы к понятию не отличались.

Наиболее распространенным является восприятие механизма в экономике как совокупности различных составляющих. Так, авторы Горанин А.И., Ефименко А.Г., Лобан Л.А.. и Маврищев В.С. определили, что хозяйственный механизм включает в себя совокупность рычагов и стимулов воздействия на экономику и экономические отношения, приведенную в определенную систему [2, 3]. При этом Ефименко А.Г. рассматривал формирование хозяйственного механизма в более узкой сфере - агропромышленном комплексе. Маевский В.Н. и Радиевский М.В. определили хозяйственный механизм как формы (планирование, стимулирование, хозрасчет, цены, финансы и их регулирование) и методы (экономические, социально-мотивационные и нормативно-административные) целенаправленного воздействия на процесс производства продукции [4]. Ряд авторов (Афанасенко А.В., Давыденко Л.Н., Золотогоров В.Г., Кузнецова Г.Ф., Лаптев Б.В., Лукин В.Б., Медведев В.Ф., Пасюк М.Ю., Стукалов Л.С.) воспринимали хозяйственный механизм как совокупность организационных структур, форм хозяйствования, методов управления, обеспечивающих функционирование экономики в определенной действительности $[5,6,7,8,9,10]$. Однако большинство вышеперечисленных формулировок хозяйственного механизма как совокупности не в полной мере отражают наличие взаимосвязей между его элементами, в итоге механизм предстает как набор разрозненных составляющих.

Некоторые авторы определяли хозяйственный механизм как способ организации общественного производства. Абалкин Л.И. полагал, что «хозяйственный механизм в самой общей форме можно охарактеризовать как способ организации общественного производства со свойственными ему формами и методами, экономическими стимулами и правовыми нормами» [1]. Действительно, такая формулировка является слишком обобщенной. Авторы Т.В. Голутвина и М.И. Круглов кроме этого полагают, что хозяйственный механизм дополняется совокупностью форм и методов взаимодействия с субъектами хозяйствования для повышения эффективности производства [11]. 
Многие авторы определяли хозяйственный механизм как систему. Афанасьев В.А. определил хозяйственный механизм как систему организации общественного производства в соответствии с присущими конкретному способу производства отношениями собственности [12]. В работах $[13,14]$ кроме форм организации и структуры общественного производства хозяйственный механизм включает формы и методы управления, экономические рычаги и стимулы, систему организационно-экономических отношений и связей. Братусь С.Н. под хозяйственным механизмом понимал систему и структуру компетентных органов, осуществляющих планово-организационное руководство народным хозяйством, систему непосредственно хозяйствующих звеньев, способы и методы такого руководства и хозяйствования [15]. Однако «система» содержит в себе понятие «структура» и предполагает наличие динамических процессов в отличие от статических структур. Такой подход сужает понятие механизма от системного подхода к структурному.

Осипов М.Ю. предложил свой особый философский подход к понятию хозяйственный механизм, который «предстает как система (сеть) взаимодействующих информационно-решающих центров, распространенная на все общество, на его центр и периферию. То есть хозяйственный механизм есть во всех смыслах общественная система, находящаяся в обществе, из общества состоящая и на общество распространенная - система-общество» [16]. Такой подход представляет собой наиболее обобщенную точку зрения, но является абстрактным и не отражает экономическую специфику хозяйственного механизма.

Многие авторы кроме понятия «хозяйственный механизм» используют категории «экономический механизм», «хозяйственный комплекс», «социальноэкономический механизм». Так, Л.И. Лопатников полагает, что термины «хозяйственный механизм» и «социально-экономический механизм» идентичны. Под ними он подразумевают «понятие, охватывающее организационнохозяйственные и социальные аспекты экономики, выражающее взаимодействие соответствующих структур и регуляторов, которые в совокупности обеспечивают функционирование экономической системы» [17]. Автор справедливо отметил, что составляющие хозяйственного механизма обеспечивают функционирование всей экономической системы.

Французские экономисты И. Беранар и Ж.-К. Колли считают, что «экономические механизмы представляют взаимосвязи и отношения между разнородными явлениями, не являются независимыми от законодательно и распорядительно определяемых рамок, в которых они функционируют» [18]. Они выделяют три основных типа экономических механизмов:

- обмены, регулирующие отношения между народными хозяйствами двух стран;

- распределение, которое внутри данного хозяйства регулирует отношения между производством и потреблением;

- использование доходов, регулирующее распределение между капиталовложениями и потреблением. 
Необходимо отметить, что в 2007 г. за разработку основ теории экономических механизмов была вручена Нобелевская премия по экономике Л. Гурвицу, Р. Майерсону, и Э. Маскину. Их разработки в основном связаны с информационным обменом между участниками экономического механизма (игроками). Сам экономический механизм представляет собой форму взаимодействия (игры) между информационным центром и всеми субъектами механизма [19].

По мнению Поддерегиной Л.И. многообразие точек зрения на понятие «хозяйственный механизм» не дает четкого представления о его содержании и структуре. Действительно, анализ теоретических источников подтвердил это. В связи с этим Поддерегина Л.И. предлагает использовать понятие «экономический механизм», который в большей степени соответствует системному характеру сущности экономических отношений и является регламентом производственных отношений. Однако анализ показал, что хозяйственный механизм наиболее часто характеризует экономические отношения на макроэкономическом уровне, а экономический механизм - применяется в более узких сферах экономической деятельности.

По мнению Шимова В.Н. «понятие «экономический механизм» в развитых странах включает два органично взаимосвязанных блока - рыночнуюсаморегуляцию и государственное регулирование» [21]. Такой подход наиболее обобщенно отражает многообразие точек зрения в отношении понятия «механизм» в экономике и условно может быть назван рыночным.

Таким образом, проведенный анализ теоретических разработок отечественных и зарубежных авторов позволил определить основные подходы к трактовке понятия «механизм» в экономике (Таблица 1).

Таблица 1 - Систематизация подходов к понятию «механизм» применительно к экономике

\begin{tabular}{|c|c|c|}
\hline $\begin{array}{l}\text { Восприятие } \\
\text { механизма }\end{array}$ & $\begin{array}{l}\text { Основные элементы } \\
\text { механизма }\end{array}$ & Авторы \\
\hline 1. Способ & общественное производство & $\begin{array}{l}\text { Абалкин Л.И., } \\
\text { лов М.И. }\end{array}$ \\
\hline \multirow[t]{3}{*}{ 2. Система } & 2.1. общественное производство & Афанасьев В.А. \\
\hline & $\begin{array}{l}\text { 2.2. формы, методы, рычаги, сти- } \\
\text { мулы }\end{array}$ & $\begin{array}{l}\text { Войткевич И.Е., Храпченков В.Г., Чеб- } \\
\text { лаков А.А. }\end{array}$ \\
\hline & 2.3. органы, центры & Братусь С.Н., Осипов М.Ю. \\
\hline \multirow[t]{2}{*}{ 3. Совокупность } & $\begin{array}{l}\text { 3.1. рычаги, стимулы, формы воз- } \\
\text { действия }\end{array}$ & $\begin{array}{l}\text { Ефименко А.Г., Горанин А.И., } \\
\text { бан Л.А., Маврищев В.С. }\end{array}$ \\
\hline & $\begin{array}{l}\text { 3.2. организационные структуры, } \\
\text { формы хозяйствования, методы } \\
\text { управления }\end{array}$ & $\begin{array}{l}\text { Азрилиян А.Н, Афанасенко А.В., Да- } \\
\text { выденко Л.Н., Золотогоров В.Г., Куз- } \\
\text { нецова Г.Ф., Лаптев Б.В., Лукин В.Б., } \\
\text { Медведев В.Ф., ПасюкМ.Ю., Стука- } \\
\text { лов Л.С. }\end{array}$ \\
\hline 4. Взаимодействие & структуры и регуляторы & Лопатников Л.И. \\
\hline $\begin{array}{l}\text { 5. Взаимосвязи и отно- } \\
\text { шения }\end{array}$ & $\begin{array}{l}\text { разнородные явления (обмен, рас- } \\
\text { пределение) }\end{array}$ & Бернар И., Колли Ж.-К. \\
\hline $\begin{array}{l}\text { 6. Форма взаимодей- } \\
\text { ствия (игры) }\end{array}$ & $\begin{array}{l}\text { экономические субъекты (игроки), } \\
\text { центр, информация }\end{array}$ & Гурвиц Л., Майерсон Р., Маскин Э. \\
\hline
\end{tabular}

Источник: разработка автора на основе [1-19] 
Таким образом, анализ показал, что не существует единства подходов к понятию механизм в экономике. В предложенных трактовках не уделено должного внимания управленческой составляющей механизма, которая в большей степени присуща понятию «организационно-экономический механизм». Организационная составляющая, как часть управления, характеризует, каким образом упорядочены элементы данного механизма, взаимосвязи и взаимоотношения между ними, направление управленческих воздействий. Кроме того, понятие «хозяйственный механизм используется для характеристики макроэкономической ситуации. Следовательно, формулировка «организационно-экономический механизм» в отличие от понятий «хозяйственный механизм» и «экономический механизм» более применима к сфере разведки, добычи и потребления воды.

Основные элементы, формирующие организационно-экономический механизм использования подземных вод в Республике Беларусь

На основе результатов произведенного исследования теоретических источников можно выделить 4 подхода к анализу механизмов в экономике.

1. Рыночный подход, рассматривающий механизм как совокупность двух органично взаимосвязанных блоков - рыночной саморегуляции и государственного регулирования в определенной экономической сфере. Такой подход является наиболее обобщенным. Это подтверждается тем, что во многих из проанализированных теоретических источников уделялось внимание как государству и его роли в механизме, так и независящим от его деятельности формам и способам организации экономической действительности. Поэтому при первичном анализе механизма в экономике, на этапе разработки его научных основ целесообразно применять рыночный подход.

2. Системный подход, подразумевающий выявление структурных элементов рассматриваемого механизма, управленческие и экономические связи между ними. Используется при более углубленном изучении механизма в экономике, когда в выделенных блоках необходимо определить составляющие их элементы и взаимосвязи между ними.

3. Процессный (управленческий) подход, рассматривающий механизм в экономике как логическую последовательность действий и/или управленческих воздействий, направленных на решение определенной задачи. Он используется для окончательной проработки научных подходов к изучению механизма, когда необходимо оценить все происходящие в механизме процессы, в том числе управленческие.

4. Функциональный подход, направленный на изучение в представленном механизме основных функций, выполняемых субъектами механизма. Данный подход не может использоваться самостоятельно без хотя бы одного из вышеперечисленных подходов и выступает дополнением к любому из них.

Все перечисленные подходы находятся в тесной взаимосвязи друг с другом.

Исходя из анализа теоретических источников белорусских и зарубежных ученых, автором предложено собственное определение механизма примени- 
тельно к предмету исследования. Организационно-экономический механизм использования подземных вод в Республике Беларусь - система, обеспечивающая взаимодействие формирующих ее субъектов по поводу использования подземных вод для хозяйственных, производственных, санитарно-гигиенических и иных целей посредством различных экономических инструментов.

На основе рыночного подхода выявлено, что в Республике Беларусь основные субъекты исследуемого организационно-экономического механизма могут быть разделены на две группы:

1. Государство в лице государственных органов и организаций, которое выполняет следующие общие функции:

- управленческая, обеспечивающая реализацию государством основных функций управления (планирование, организация, контроль и т.д.), необходимость которых возникает в связи с использованием различными субъектами подземных вод;

- правовая, реализация которой направлена на создание нормативных правовых актов, регулирующих деятельность в области использования подземных вод;

- распределительная, которая характеризует, каким образом распределяются и перераспределяются доходы хозяйствующих субъектов в связи с использованием подземных вод;

- экологическая - направлена на обеспечение устойчивого развития экономики и сохранения водных ресурсов для будущих поколений.

Основными инструментами, предназначенными для реализации функций государства в механизме, являются:

- экономические методы;

- нормативно-правовые акты;

- организационно-правовые формы.

2. Субъекты, осуществляющие использование подземных вод. Основными их функциями являются:

- добыча подземных вод;

- производственное и непроизводственное потребление подземных вод;

- реализация продукции, произведенной с использованием подземных вод.

С учетом реализуемых экономических функций участников процессов добычи и потребления водных ресурсов в Республике Беларусь можно подразделить на несколько групп. Каждой из групп присуще сходство составляющих ее субъектов по выполняемой специфической роли в организационноэкономическом механизме использования подземных вод.

1. Органы государственного регулирования, которые можно подразделить на три подгруппы: органы общего государственного управления; органы специального государственного управления; органы ведомственного отраслевого и функционального управления.

2. Предприятия, использующие водные ресурсы в санитарно-бытовых целях, в технологическом процессе, как сырье для производства. 
3. Санаторно-курортные организации, оказывающие лечебнопрофилактические услуги с использованием минеральных вод.

4. Потребители воды как продукта предприятий-производителей и санаторно-курортных организаций.

5. Организации агропромышленного комплекса (АПК), использующие воду в бытовых целях и в производственном процессе.

6. Организации жилищно-коммунального хозяйства (ЖКХ), которые обеспечивают водой домашние хозяйства и организации для удовлетворения санитарно-бытовых, производственных и иных потребностей.

Безусловно, функционирование вышеперечисленных участников осуществляется во взаимодействии с организациями, непосредственно использующими водные ресурсы только в бытовых целях, при этом обеспечивающими нормальную работу всех участников организационно-экономического механизма: поставщики сырья, материалов и комплектующих, банковские, транспортные, финансовые, торговые, логистические, научные, гидрогеологические организации и т.д.

Исследуемый механизм формируется и существует благодаря взаимодействию представленных выше субъектов с учетом общих экономических законов, инструментов, благодаря которым оно реализуется, и ограничений, обусловленной средой их функционирования.

Состояние современного организационно-экономического механизма использования подземных вод в Республике Беларусь и основные направления его совершенствования

Исходя из множества нужд и потребностей, удовлетворяемых с помощью подземных вод, укрупненный анализ их использования можно осуществлять по трем основным направлениям: разведка, добыча и потребление. На рисунке 1 представлена схема сложившегося в республике организационноэкономического механизма использования подземных вод. 




Рисунок 1 - Схема организационно-экономического механизма использования подземных вод в Республике Беларусь

В организационно-экономическом механизме использования подземных вод государство в лице государственных органов и организаций имеет особое значение и выполняет две основные роли. Во-первых, государство является собственником водных ресурсов. Согласно ст.4 Водного Кодекса Республики Беларусь «Все воды (водные объекты), находящиеся на территории Беларуси, составляют исключительную собственность Республики Беларусь». Во-вторых, государство формирует организационно-экономические условия, в которых функционируют все остальные участники исследуемого механизма (денежнокредитную, налоговую, таможенную политику, порядок ценообразования, санитарно-гигиенический контроль и т.д.) посредством утверждения и контроля соблюдения требований нормативно-правовых актов, регулирующих деятельность хозяйствующих субъектов.

Анализ сложившегося организационно-экономического механизма использования подземных вод в Республике Беларусь и разработка рекомендаций по его совершенствованию, осуществлялась по основным направлениям эксплуатации подземных вод. В анализе рассматривались наиболее важные их составляющие: пресные воды, используемые во всех сферах экономики, и минераль- 
ные воды, которые применяются, в основном, в лечебно-профилактических целях.

Разведка подземных вод. Оценка разведанности запасов подземных вод в Республике Беларусь произведена на основе анализа утвержденных эксплуатационных запасов. Эксплуатационные запасы подземных вод - количество подземных вод, которое может быть получено на месторождении подземных вод (участке месторождения) или автономном эксплуатационном участке из геолого-технически обоснованных водозаборных сооружений, при заданном режиме эксплуатации и качестве воды, удовлетворяющем требованиям ее целевого использования в течение расчетного срока эксплуатации с учетом природоохранных и санитарных требований и ограничений, а также экономической целесообразности их использования [22].

В таблице 2 отражены утвержденные эксплуатационные запасы минеральных вод на 1.01.2009 г. по категориям и территориальным областям Республики Беларусь.

Таблица 2 - Утвержденные эксплуатационные запасы минеральных вод Республики Беларусь на 1.01.2009 г.

\begin{tabular}{|l|l|l|l|l|l|l|}
\hline \multirow{2}{*}{\multicolumn{1}{c|}{ Область }} & \multirow{2}{*}{ Количество } & \multicolumn{5}{c|}{ Эксплуатационные запасы, ${ }^{3} /$ сутки } \\
\cline { 5 - 8 } & \multicolumn{1}{c|}{ месторождений } & \multicolumn{1}{c|}{$\mathrm{A}$} & \multicolumn{1}{c|}{$\mathrm{C}_{1}$} & \multicolumn{1}{c|}{$\mathrm{C}_{2}$} & Всего \\
\hline Брестская & 18 & 164,8 & 540,3 & 1515,55 & 49,0 & 2269,65 \\
\hline Витебская & 24 & 991,5 & 1605,51 & 18502,39 & 0 & 21099,4 \\
\hline Гомельская & 67 & 584,7 & 5579,27 & 7735,43 & 0 & 13899,4 \\
\hline Гродненская & 9 & 0,1 & 41,39 & 511,3 & 2185,5 & 2738,29 \\
\hline Минская & 75 & 987,35 & 4484,51 & 9095,72 & 314,0 & 14881,58 \\
\hline Могилевская & 34 & 140,0 & 991,76 & 2942,94 & 0 & 4074,7 \\
\hline $\begin{array}{l}\text { Всего по Респуб- } \\
\text { лике Беларусь }\end{array}$ & 227 & 2868,45 & 13242,74 & 40303,33 & 2548,5 & 58963,02 \\
\hline
\end{tabular}

Примечание - по данным[23]

Из данных таблицы 2 следует, что всего в Республике Беларусь утверждены запасы минеральных вод в объеме 58963,02 м³/сутки; наиболее обеспеченными запасами минеральных подземных вод являются Витебская и Минская области, наименее обеспеченной - Брестская.

Важнейшим ресурсом, обеспечивающим эффективное функционирование экономики, являются пресные подземные воды. В таблице 3 представленные данные об утвержденных эксплуатационных запасах пресных подземных вод в 2011 г. по категориям и территориальным областям Республики Беларусь. 
Таблица 3 - Утвержденные эксплуатационные запасы пресных подземных вод в 2011 году по категориям и территориальным областям Республики Беларусь

\begin{tabular}{|l|l|l|l|l|l|l|}
\hline \multirow{2}{*}{\multicolumn{1}{c|}{ Область }} & \multirow{2}{*}{$\begin{array}{c}\text { Количество место- } \\
\text { рождений }\end{array}$} & \multicolumn{5}{|c|}{ Эксплуатационные запасы, тыс. $\mathrm{m}^{3} /$ сут. } \\
\cline { 3 - 7 } & 42 & 408,2 & 386,5 & 82,4 & 10,0 & 887,2 \\
\hline Брестская & 42 & 440,8 & 254,2 & 198,5 & - & 893,5 \\
\hline Витебская & 32 & 588,9 & 419,5 & 141,8 & 10,0 & 1160,3 \\
\hline Гомельская & 69 & 319,2 & 368,2 & 126,9 & - & 814,3 \\
\hline Гродненская & 33 & 1005,5 & 857,1 & 222,4 & 415,5 & 2500,5 \\
\hline Минская & 77 & 523,7 & 213,2 & 100,6 & - & 837,5 \\
\hline Могилевская & 44 & 3286,4 & 2498,7 & 872,7 & 435,5 & 7093,3 \\
\hline РеспубликаБеларусь & 297 & & & & \\
\hline
\end{tabular}

Примечание - по данным[23]

Как видно из таблицы 3, республика обладает значительными запасами пресных подземных вод. Проведенные исследования позволили определить, что наиболее обеспеченными эксплуатационными запасами является Минская и Гомельская области, наименее обеспеченной - Гродненская.

Однако, по мнению некоторых белорусских гидрогеологов, нельзя с полной уверенностью говорить о достоверности этих данных. Так, например, членкорреспондент НАН Беларуси ученый-гидрогеолог Кудельский А.В. утверждает, что к настоящему времени в Республике Беларусь нет достоверной информации о количестве прогнозных естественных ресурсов и эксплуатационных запасов подземных вод. Это объясняется тем, что[24]:

- во-первых, запасы рассчитывались более 35 лет назад и за истекшее время существенно изменилась техногенная нагрузка на подземные воды;

- во-вторых, ужесточились требования к изучению запасов и качества подземных вод;

- в-третьих, прежняя методика аналитических расчетов запасов подземных вод существенно устарела.

По данным БелНИГРИ, к 2006 году по 79 водозаборам подземных вод срок эксплуатации уже истек, а к 2010 году - еще по 45 водозаборам, что ставит перед геологической службой республики проблему переоценки запасов пресных подземных вод по 124 скважинным водозаборам. Особую озабоченность в настоящее время вызывает проблема водоснабжения столицы Республики Беларусь г. Минска: по большинству водозаборов (Новинки, Петровщина, Зеленовка, Дражня, Боровляны, Островы, Волма, Водопой, Фелицианово, Зеленый Бор) расчетный срок эксплуатации $(27,4$ года) уже истек. И хотя по некоторым из них эксплуатационные запасы подземных вод были рассчитаны на неограниченный срок использования, из-за случившихся локальных загрязнений подземных водоносных горизонтов переоценку эксплуатационных запасов следует провести по всем водозаборам. Без проведения подобной переоценки нереальной представляется и проблема полного перевода водоснабжения г. Минска на подземные водоисточники [24]. 
Проблема достоверности оценки запасов подземных вод подтверждается данными Программы освоения месторождений полезных ископаемых и развития минерально-сырьевой базы Республики Беларусь на 2011 - 2015 годы и на период до 2020 года. Программой предусматриваются мероприятия в части поиска и разведки пресных и минеральных подземных вод, которые содержат: введение актуализированной базы данных (качество, уровни, водоотбор, ресурсы, запасы) одиночных эксплуатационных скважин пресных и минеральных подземных вод по данным паспортизации скважин питьевого водоснабжения; геофильтрационные и геомиграционные модели подземных вод; прогнозные карты изменения качества и уровней вод.

Добыча подземных вод. Анализ данных Государственного геологического фонда Республики Беларусь, свидетельствует о том, что утвержденные эксплуатационные запасы подземных вод используется не в полном объеме $[25,26]$. В таблице 4 представлена информация, характеризующая использование эксплуатационных запасов минеральных вод в Республике Беларусь.

Таблица 4 - Использование эксплуатационных запасов минеральных вод Республики Беларусь на 1.01.2009 г.

\begin{tabular}{|c|c|c|c|c|c|c|}
\hline \multirow{2}{*}{$\begin{array}{c}\text { Количество } \\
\text { скважин }\end{array}$} & \multicolumn{6}{|c|}{ Эксплуатационные запасы, м³/сутки } \\
\hline & A & $\mathrm{B}$ & $\mathrm{C}_{1}$ & $\mathrm{C}_{2}$ & $\mathrm{~A}+\mathrm{B}+\mathrm{C}_{1}$ & Всего \\
\hline 227 & 2868,45 & 13242,74 & 40303,33 & 2548,5 & 56414,52 & 58963,02 \\
\hline \multicolumn{7}{|c|}{ Из них эксплуатируется } \\
\hline 106 & 2808,2 & 10734,73 & 26397,91 & - & 39941,34 & 39940,84 \\
\hline \multicolumn{7}{|c|}{ Из них не эксплуатируется } \\
\hline 121 & 60,25 & 2508,01 & 13905,42 & 2548,5 & 16473,18 & 19022,18 \\
\hline \multicolumn{7}{|c|}{ \% неэксплуатируемых в общем объеме эксплуатационных запасов } \\
\hline 53,30 & 2,10 & 18,94 & 34,50 & 100 & 29,31 & 32,26 \\
\hline
\end{tabular}

Примечание - разработка автора на основе данных [27]

Из таблицы 4 следует, что используется около 67 \% общего объема утвержденных эксплуатационных запасов минеральных вод республики Беларусь.

Примерно десятая часть разведанных запасов применяется в деятельности санаториев и профилакториев республики. На данный момент в республике действует порядка 90 санаторно-курортных организаций и лечебных учреждений, на балансе которых числятся скважины минеральной воды для лечебных целей.

Согласно данным Программы освоения месторождений полезных ископаемых и развития минерально-сырьевой базы Республики Беларусь на 2011 2015 годы и на период до 2020 года подготовку к разработке и разработку новых месторождений минеральных вод в Республике Беларусь планируется осуществить за счет строительства и ввода в эксплуатацию предприятий по розливу минеральных подземных вод.

Еще в меньшей степени используются запасы пресных подземных вод. В настоящее время разведано только 14,3\% прогнозных ресурсов. Потенциальные 
возможности использования подземных вод характеризуются их естественными ресурсами, которые составляют 43560 тыс.м3/сут.

Государственным водным кадастром учтены эксплуатационные запасы пресных подземных вод в количестве 7093,3 тыс.м3/сут., в том числе 435,5 тыс.м3/сут. апробированные эксплуатационные запасы категории С2. Эксплуатационные запасы пресных подземных вод питьевого и хозяйственного назначения разведаны на 297 участках месторождений пресных подземных вод.

Анализ динамики утвержденных эксплуатационных запасов пресных подземных вод Республики Беларусь показал, что произошло увеличение объема балансовых запасов пресных подземных вод за счет разведки и утверждения на 771,6 тыс. м $^{3}$ / сутки (12\%). В 2011 году объем изъятия водных ресурсов из подземных источников увеличился по сравнению с 2010 годом на 40 млн/м³ и составил 1638 млн/м³ . При этом объем добычи утвержденных эксплуатационных запасов пресных подземных вод Республики Беларусь составляет не более 70 \% [25], а по отношению к прогнозным запасам - около $10 \%$.

Таким образом, анализ показал, что в Республике Беларусь имеются значительные резервы утвержденных эксплуатационных запасов подземных вод (около 30 \% пресных и минеральных вод), которые можно использовать в большей степени для получения дополнительного социально-экономического эффекта без нанесения ущерба качеству воды и состоянию окружающей среды. Поскольку водные ресурсы относятся к возобновляемым, то использование их в пределах утвержденных эксплуатационных запасов не нарушает экологической обстановки.

Потребление подземных вод. Для оценки того, каким образом используются имеющиеся запасы подземных вод в Республике Беларусь, рассмотрим некоторые показатели (Таблица 5).

Таблица 5 - Забор воды и ее использование в Республике Беларусь в 20052011 гг.

\begin{tabular}{|l|l|l|l|l|l|l|l|}
\hline \multicolumn{1}{|c|}{ Показатель } & 2005 & 2006 & 2007 & 2008 & 2009 & 2010 & 2011 \\
\hline $\begin{array}{l}\text { Забор воды из всех природных ис- } \\
\text { точников, млн м }\end{array}$ & 1706 & 1674 & 1618 & 1566 & 1507 & 1548 & 1592 \\
\hline $\begin{array}{l}\text { в том числе из подземных горизон- } \\
\text { тов, } \\
\text { в млн м }\end{array}$ & 1012 & 987 & 938 & 896 & 835 & 854 & 870 \\
\hline в \% & 59,3 & 59,0 & 58,0 & 57,2 & 55,4 & 55,2 & 54,6 \\
\hline $\begin{array}{l}\text { Забор воды из всех природных ис- } \\
\text { точников, приходящийся на одного } \\
\text { жителя, м }\end{array}$ & 175,9 & 173,8 & 168,9 & 164,1 & 158,4 & 162,9 & 167,9 \\
\hline Использовано воды, млн м & & & & & & \\
\hline в том числе: & 1600 & 1546 & 1485 & 1410 & 1337 & 1359 & 1406 \\
\hline - на производственные нужды & 723 & 704 & 716 & 723 & 721 & 750 & 806 \\
\hline из них питьевого качества, млн м & 151 & 149 & 150 & 154 & 144 & 154 & 154 \\
\hline $\begin{array}{l}\text { \% от использованной воды на про- } \\
\text { изводственные нужды }\end{array}$ & 21 & 21 & 21 & 21 & 20 & 21 & 19 \\
\hline - на хозяйственно-питьевые нужды & 750 & 708 & 653 & 574 & 501 & 495 & 486 \\
\hline $\begin{array}{l}\text { - на орошение и сельскохозяйствен- } \\
\text { ное водоснабжение }\end{array}$ & 127 & 134 & 116 & 113 & 115 & 114 & 114 \\
\hline
\end{tabular}


Источник: на основе данных[27]

Из данных таблицы 5 видно, что добыча воды из подземных горизонтов Республики Беларусь составляет более 50 \% забора из всех природных источников. Это подтверждает значимость подземных вод в общем объеме водных ресурсов, используемых для функционирования экономики, а также отдельных организаций и граждан Республики Беларусь. Анализ использования воды на различные нужды показывает, что больший объем обеспечивает деятельность производственного сектора экономики, при этом около 20 \% этих вод - питьевого качества, что является не вполне целесообразным направлением использования такого важного ресурса.

Структура распределения использования воды в зависимости от целей представлена на рисунке 2.

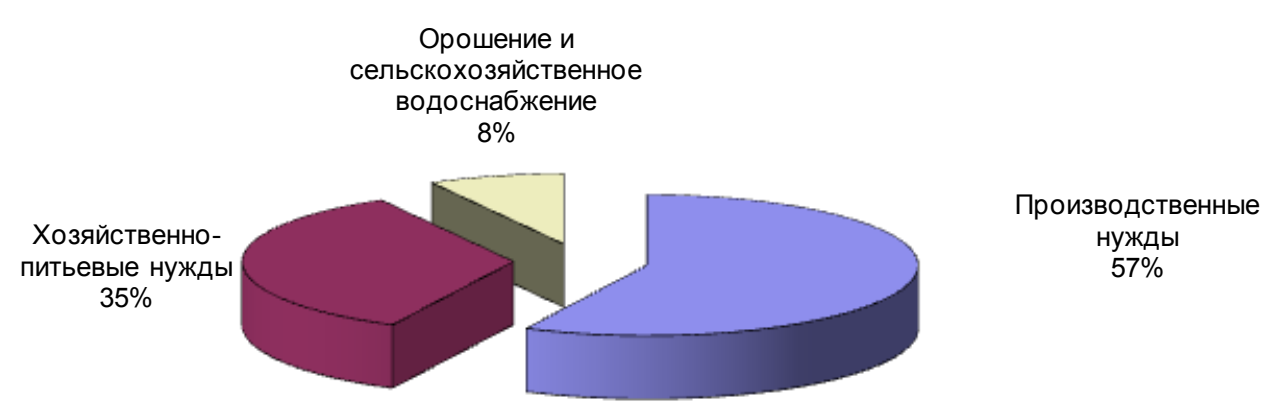

Рисунок 2 - Структура использования воды в Республике Беларусь в 2011 г.

На хозяйственно-питьевые нужды в республике используется $35 \%$ всех объемов добываемых вод. С целью повышения эффективности этого направления в Республике Беларусь утверждена Государственная программа по водоснабжению и водоотведению «Чистая вода» на 2011 - 2015 годы, разработанная в развитие аналогичной программы на период 2006 - 2010 годы. Согласно данным программы, несмотря на выполнение значительного объема работ по развитию централизованного водоснабжения и водоотведения, в республике остаются нерешенными следующие проблемы:

- недостаточный уровень обеспеченности населения централизованным водоснабжением, особенно в сельской местности (не обеспечено около 1,4 млн. человек, в том числе 0,3 млн. человек городского и 1,1 млн. человек сельского населения);

- недостаточный уровень обеспеченности населения питьевой водой нормативного качества из систем централизованного водоснабжения (около 2 млн. человек используют воду с содержанием железа выше санитарной нормы - 0,3 миллиграмма на литр);

- несоответствие санитарным требованиям воды из источников нецентрализованного водоснабжения; в настоящее время этими источниками пользуют- 
ся около 1,5 млн. человек; около 40 процентов исследованных проб не соответствовали требованиям по санитарно-химическим и около 16 процентов - по микробиологическим показателям;

- высокий физический износ очистных сооружений канализации, отсутствие современных технологий и оборудования для очистки сточных вод, в том числе от биогенных элементов (азота и фосфора), а также недостаточный уровень автоматизации и диспетчеризации технологических процессов;

- сброс в централизованные системы водоотведения недостаточно очищенных производственных сточных вод вследствие несовершенства технологий очистки и неудовлетворительной эксплуатации действующих локальных очистных сооружений.

В результате использовании воды в деятельности хозяйствующих субъектов происходит сброс сточных вод различной степени загрязнения (таблица 6), что влияет на качество водных ресурсов Республики Беларусь, в том числе подземных вод благодаря естественному обороту воды в природе, а также общую экологическую обстановку.

Таблица 6 - Отведение сточных в поверхностные водоемы Республики Беларусь по степени их очистки в 2005-2010 гг.

\begin{tabular}{|c|c|c|c|c|c|c|}
\hline Показатель & 2005 & 2006 & 2007 & 2008 & 2009 & 2010 \\
\hline $\begin{array}{l}\text { Общий объем отведенных сточных } \\
\text { вод, млн м }\end{array}$ & 1124 & 1059 & 1015 & 966 & 974 & 967 \\
\hline $\begin{array}{l}\text { в том числе: } \\
\text { без очистки } \\
\text { млн м } \\
\text { \% от общего объема }\end{array}$ & $\begin{array}{l}268 \\
23,8 \\
\end{array}$ & $\begin{array}{l}233 \\
22,0\end{array}$ & $\begin{array}{l}246 \\
24,2 \\
\end{array}$ & $\begin{array}{l}246 \\
25,5\end{array}$ & $\begin{array}{l}286 \\
29,4\end{array}$ & $\begin{array}{l}290 \\
30,0 \\
\end{array}$ \\
\hline $\begin{array}{l}\text { нормативно очищенных } \\
\text { млн м } \\
\text { \% от общего объема }\end{array}$ & $\begin{array}{l}846 \\
75,3 \\
\end{array}$ & $\begin{array}{l}817 \\
77,1\end{array}$ & $\begin{array}{l}860 \\
84,7 \\
\end{array}$ & $\begin{array}{l}709 \\
73,4 \\
\end{array}$ & $\begin{array}{l}685 \\
70,3\end{array}$ & $\begin{array}{l}671 \\
69,4 \\
\end{array}$ \\
\hline $\begin{array}{l}\text { недостаточно очищенных } \\
\text { млн м } \\
\text { \% от общего объема }\end{array}$ & $\begin{array}{l}10 \\
0,9\end{array}$ & $\begin{array}{l}9 \\
0,8\end{array}$ & $\begin{array}{l}9 \\
0,8\end{array}$ & $\begin{array}{l}11 \\
1,1\end{array}$ & $\begin{array}{l}3 \\
0,3\end{array}$ & $\begin{array}{l}6 \\
0,6\end{array}$ \\
\hline
\end{tabular}

Источник: на основе данных [27]

Как видно из данных таблицы 6, общий объем отведенных сточных вод по Республике Беларусь устойчиво снижается, при этом объем сточных вод без очистки увеличивается. Удельный вес вод, сбрасываемых в поверхностные источники без очистки, увеличился почти на 7 процентных пунктов. Объем нормативно очищенных сточных вод за исследуемый период снизился. Все эти данные свидетельствуют о том, что нагрузка на окружающую среду в области водных ресурсов возрастает и ухудшается общая экологическая обстановка в Республике Беларусь и странах, связанный с ней трансграничными водами. Это подтверждается данными Национального статистического комитета Республики Беларусь по уровню загрязненности воды в отдельных реках [28].

Грунтовые воды, а во многих местах и глубоко залегающие напорные, загрязнены нитратами, тяжелыми металлами, высокотоксичными металлоргани- 
ческими ионными композициями, пестицидами, а также легко летучими органическими веществами высоких классов опасности (бензол, транс-1,2дихлорэтилен, фенол, анилин, сероуглерод и др.) [24].

Кроме того, имеет значение проблема снижения уровня подземных вод в Минской области, что связано с большой антропогенной и техногенной нагрузкой данного региона. В процессе эксплуатации подземных вод Минской городской агломерации, по утверждению Кудельского А.В., значительно понизились их уровенные поверхности, что привело к снижению подземного питания рек и ухудшению условий произрастания растительности в зеленых зонах. В пределах г. Минска и прилегающей территории отдельные речные водотоки перестали существовать и о них напоминают лишь осушенные речные долины. Пересохли верховья некоторых рек (Слепянка, Лошица с Мышкой, Тростянка, Цна, Волма, Сенница, Качинка), а реки Переспа, Немига, Дражня заключены в подземные ливневые коллекторы. Все это свидетельствует о том, что в перспективе при максимальной нагрузке водозаборов до величины ранее утвержденных запасов, возможно, произойдет сработка не только емкостных запасов грунтовых горизонтов, но упругих запасов эксплуатируемых горизонтов с выходом из строя городских водозаборов [24].

\section{ВЫВОДЫ}

На основе проведенного анализа выявлены некоторые проблемы функционирования сложившегося в Республике Беларусь организационноэкономического механизма использования подземных вод Республике Беларусь. Исходя из этого, можно предложить основные направления его совершенствования.

1. Переоценка имеющихся в республике запасов подземных пресных и минеральных вод, необходимость которой обусловлена устареванием имеющихся данных по утвержденным эксплуатационным запасам, изменением состояния подземных вод в последние годы и методики их определения.

2. Снижение нагрузки на подземные водоносные горизонты г. Минска и Минской области за счет:

- строительства и введения в эксплуатацию новых водоемких производств за пределами Минской области;

- перемещения водоемких производств, находящихся в г. Минске и Минской области, в другие области Республики Беларусь с достаточным уровнем запасов;

- применения экономических механизмов стимулирования снижения водоемкости производственных процессов (например, разработка механизмов льготного налогообложения, кредитования предприятий, внедряющих водосберегающие технологии).

3. Обеспечение безопасной водой как можно большего числа жителей Республики Беларусь за счет обновления технических систем централизованного водоснабжения, ликвидации изношенного оборудования, ухудшающего качество воды, поступающей к потребителям. 
4. Увеличение объемов вовлечения подземных вод Республики Беларусь в хозяйственный оборот с учетом экологического фактора, что повысит коэффициент их использования. Поскольку водные ресурсы относятся к возобновляемым, то использование их в пределах утвержденных эксплуатационных запасов не нарушает экологической обстановки. Основными направлениями повышения объемов использования подземных вод могут быть:

- увеличение объемов производства бутилированных минеральных и пресных подземных вод для реализации на внутреннем и внешних рынках;

- увеличение объемов реализации услуг санаторно-профилактических организаций с использованием минеральных вод и рассолов населению Республики Беларусь и иностранным туристам.

Вышеперечисленные мероприятия позволят улучшить функционирование организационно-экономического механизма использования подземных вод в Республике Беларусь за счет повышения эффективности использования минеральной и пресной воды.

\section{ЛИТЕРАТУРА}

1. Абалкин, Л.И. Избранные труды: в 4-х т. / Л.И. Абалкин. - Москва : ОАО «НПО «Экономика», 2000. - Т. 2: На пути реформе: хозяйственный механизм развитого социалистического общества; новый тип экономического мышления; перестройка: пути ипроблемы: статьи интервью, выступления / сост. Грибанова О.М. - 2000. - 911 с.

2. Совершенствование хозяйственного механизма / А.И. Горанин [и др.]; под ред. А.И. Горанина [и др.]. - Минск :Вышэйшая школа. - 1989. - 214 с.

3. Ефименко, А.Г. Экономический механизм рыночных отношений в системе автотранспортного обслуживания АПК :моногр. / А.Г. Ефименко. Минск : БГЭУ, 2006. -215 с.

4. Маевский, В.Н. Экономический механизм оперативного управления производством на предприятии в условиях регулируемого рынка / В.Н. Маевский, М.В. Радиевский // Минск:БелНИИНТИГосэкономплана БССР, 1990. -48 c.

5. Государственное регулирование социально-экономических отношений. / Л.Н. Давыденко [и др.]; под общ.ред. Давыденко Л.Н. - Минск, 1996. - 278 с.

6. Хозяйственное право. Общие положения / В.В. Лаптев [и др.] ; под ред. В.В. Лаптева. - Москва : Наука. - 1983. - 287 с.

7. Экономический словарь / В. Г. Золотогоров, Г. Ф. Кузнецова, М.Ю. Пасюк. - 2-е изд., перераб. и доп. - Минск :НавукаІтэхніка, 1990. - 415 с.

8. Медведев, В.Ф. Совершенствование хозяйственного механизма в европейских социалистических странах / В.Ф. Медведев, А.В. Афанасенко // Минск :БелНИИНТИ Госплана БССР, 1988. - 60 с.

9. Стукалов, Л.С. Хозяйственный механизм атотранспорта в условиях рыночной экономики / Л.С. Стукалов. - Минск :Вышэйшая школа, 1993. - 87 с. 
10. Лукин, В.Б. Ценообразование [Электронный ресурс]. - Минск, 2007. Режим доступа :www.hi-edu.ru/e-books/xbook102/01/part-002.htm. - Дата доступа :21.09.2010.

11. Основы управления экономикой и хозяйственный механизм : учебное пособие / Т.В. Голутвина, М.И. Круглов // Российский заочный институт текстильной и легкой промышленности : Москва, 1993. - 91 с.

12. Совершенствование хозяйственного механизма в легкой промышленности : сборник научных трудов / под общ.ред. В.А. Афанасьева. - Москва : ЦНИИТЭИлегпром, 1994. - 206 с.

13. Храпченков, В.Г. Экономический механизм хозяйствования и пути его совершенствования / В.Г. Храпченков, И.Е. Войткевич. - Минск : Вышэйшая школа. - 1980.- $222 \mathrm{c.}$

14. Чеблаков, А.А. XXIV съезд КПСС о совершенствовании управления экономикой (Материал в помощь лектору) / А.А. Чеблаков. - Минск : Общество «Знание», 1982. - 23 с.

15. Братусь, С.Н. Право и хозяйственный механизм/ С.Н. Братусь // Правоведение. - 1983. - №4. - С. 29-37.

16. Осипов, Ю.М. Основы теории хозяйственного механизма / Ю.М. Осипов. - Москва: Издательство МГУ, 1994 - 368 с.

17. Лопатников, Л.И. Экономико-математический словарь Л.И. Лопатников. - 4-е изд., доп. и перераб. - Москва : Издательство «АВF», 1996. $-704 \mathrm{c}$.

18. Бернар, И. Толковый экономический и финансовый словарь: французская, русская, английская, немецкая, испанская терминология: В 2-х тт. - Пер. с фр.. / И. Беранар, Ж.-К. Колли. - Москва, 1997. - Т.ІІ - 760с.

19. Измалков, С. Теория экономических механизмов / С.Измалков, К. Сонин, М. Юдкевич // Вопросы экономики [Электронный ресурс]. - 2008. - №1 . Режим доступа : http://institutiones.com/general/259--2007-1.html. - Дата доступа : 12.04.2011.

20.Поддерегина, Л.И. Экономический механизм внутрипроизводственных отношений на предприятии: монография / Л.И. Поддерегина, Э.М. Гайнутдинов. - Минск: МГВРК, 2004. - 304 с.

21. Национальная экономика Беларуси: Потенциалы. Хозяйственные комплексы. Направления развития. Механизмы управления : Учеб.пособие / В.Н. Шимов, Я.М. Александрович, А.В. Богданович [и др.]; под общ. ред. В.Н. Шимова. - Минск : БГЭУ, 2005. - 844 с.

21. Об утверждении Инструкции о классификации запасов, перспективных и прогнозных ресурсов углеводородов, эксплуатационных запасов и прогнозных ресурсов подземных вод: постановление Министерства природных ресурсов и охраны окружающей средыРесп. Беларусь, 4 августа 2009 г., №55 // Нац. реестр правовых актов Респ. Беларусь. - 2009. - 8/21447.

23. Официальный сайт Министерства природных ресурсов и охраны окружающей среды Республики Беларусь [Электронный ресурс] // Режим доступа: http://minpriroda.gov.by. 
24. Кудельский, А.В. Пресные подземные воды как основной источник питьевого водоснабжения в Республике Беларусь: ресурсы, качество, проблемы водопользования // Стратегические проблемы охраны и использования водных ресурсов : материалы IV Междунар. вод. форума, Минск, 12-13 окт. 2010 г. / М-во природ. ресурсов и охраны окружающей среды Респ. Беларусь, Центр. науч.-исслед. ин-т комплексного использования водных ресурсов. - Минск, 2011. - C. 18-30.

25. Скворцова, Е.В. Состояние, тенденции и перспективы использования пресных питьевых и минеральных вод в Республике Беларусь/ Г.Т.Кулаков, Е.В. Скворцова // Труд. Профсоюзы. Общество. - 2008. - №1. - С. 6-9.

26.Скварцова, А.В. ПраблемыіперспектывывыкарыстанняпрэснайвадыўсвецеіРэспубліцыБеларусь / Г.Ц. Кулакоў, А.В. Скварцова // ВесціБДПУ. Серыя 2, Гісторыя. Філасофія. Паліталогія. Сацыялогія. Эканоміка. Культуралогія. - 2008. - № 3. - С. 84-88.

27. Официальный сайт Национального статистического комитета Республики Беларусь [Электронный ресурс] // Режим доступа:http://belstat.gov.by/.

28. Охрана окружающей среды в Республике Беларусь. Статистический сборник //Ред. коллегия: И.С. Кангро [и др.]. - Минск: Национальный статистический комитет Республики Беларусь, 2012. - 260 с. 